SHS Web of Conferences 23, 04003 (2016)

DOI: $10.1051 /$ shsconf/20162304003

(C) Owned by the authors, published by EDP Sciences, 2016

\title{
JOM BACA@PHS: BUILDING FOUNDATION FOR LIFELONG LEARNING
}

Mohd Kamal Mohd Napiah, Nor Azan Ibrahim, Intan Haryati Ibrahim, Rosnani Ahmad, Fujica Azura Fesal, Noor Adilah Azmi, Muhammad Hanifah Mahabat@ Mohamed, Hazwani Jamaluddin, Hazaralie Ramlee, Mohd Hezri Mansor, Muhamad Amin Azmi and Mohd Hazlee Abdul Halil

\author{
Hamzah Sendut Library, Universiti Sains Malaysia \\ 11800 USM, Pulau Pinang, MALAYSIA \\ mohdkamal@usm.my
}

\begin{abstract}
Universiti Sains Malaysia (USM) is a pioneering university that strives to empower future talent and next generation towards a sustainable knowledge transformation. Hamzah Sendut Library in supporting this effort has formed the Reading Campaign Committee with the tagline 'Jombaca@PHS'. This committee is established to promote love for books and reading culture to Universiti Sains Malaysia (USM) community in particular and society in general. The Library realizes that the expertise to manage reading materials shouldn't be keep by its own, but rather to be shared to others in need. Since its inception in 2009, various programs have been carried out to meet the objective. Numerous programs were conducted under three main programs, namely Community Network, Exhibition and Sharing is Caring. Starting as small-scale projects, now these initiatives have shown its positive impacts especially in building foundation for lifelong learning among USM community.
\end{abstract}

Keywords: Library, reading campaign, jombaca, community network, Universiti Sains Malaysia 


\subsection{INTRODUCTION}

The greatest gift is a passion for reading. Once you learn to read, you will be forever free

Library is synonym with books and knowledge. As books and knowledge keeper, administration of library materials is part of its specialty. Since its establishment in 1969, Hamzah Sendut Library (PHS) has been involved in managing the library to cater the needs of its customer. Therefore, PHS sees this expertise should not be keeping by itself, but rather be shared with others especially those outside USM who are having a library, but unable to manage it well.

Jombaca@PHS is a brand introduced by Reading Campaign Committee, Hamzah Sendut Library in order to carry out reading-related activities. This committee is established to promote love for books and reading culture to Universiti Sains Malaysia (USM) community in particular and society in general.

Since its inception in 2009, various programs have been carried out to meet the objective. Programs are conducted under three main programs, namely Community Network, Exhibition and Sharing is Caring. It is hope that these small efforts would bring positive impact to all especially the USM members.

\subsection{LITERATURE REVIEW}

\subsection{Reading Initiative}

There is various definition of reading and it can be interpreted according to one's understandings. Usually reading involves the act to analyze the sentence and derived imagination to express the character or a story in a book for whatever the book is all about. Among the definitions that were well understood are as follows:

Reading is a process of acquiring information in a meaningful way. Some view reading as a complex process integrating all aspects of human behaviors and demanding varied and continued instructional guidance to read accurately, to appraise and to relate to others in a significant way. (Buzan, 2006) 
While Mary Clays (1991) defined reading as:

A message-getting, problem-solving activity which increases in power and flexibility the more it is practiced.

Definitely there are more meaningful quotes or definitions that can be used in order to illustrate the meaning or act of reading. However, it all depends on the activity itself and people who doing it according to their own purposes.

Poulter (2007) in his literature review on reading habits elaborate the Blackburn opinions of the responsibility among librarians in this reading culture by stating that:

The librarian is very much concerned with the mental and spiritual stamina of the people, of their ability to meet new ideas critically and with a sufficient background of knowledge to enable them to recognise the shallow and meretricious. In short, if we believe in a democratic society, we wish to see it creative, well-balanced and intelligent.

It can be concluded that, librarians' plays important roles in nurturing the reading habits, not only in the academic environment but to all people or society nearby to strengthen the community with the ability to adjust to healthy mind and their environment wellbeing.

\subsection{Library Community Network}

Mason (1977) quotes in the technical reports that reading readiness skills are acquired, then, in a manner that integrates reading with play and other everyday activities; as a result, the children do not think that it is difficult to learn to read. It is not difficult to implement at home, preschool and kindergarten settings where reading activities can be fostered through play, art, music, field trips, storytelling, reading, and talking about letters and words.

According to Tess Prendergast (2011), in her article mentioned that the Early Years Community Program at the Vancouver Public Library was created to respond to a wellestablished need for young children to grow up in environments rich in language, literacy and learning opportunities. The Early Years Community Program adheres to a philosophy of service that is strength-based and respectful of the diversity of Vancouver's communities. They believe this strength-based philosophy, as well as their collaborative and communityled service model, results in programs, services, and collections that respond to and reflect 
the needs of the families they serve and will best prepare young children for later learning success in school and in life.

Based on the paper written by Ana Bela Martins and Alexandra Marques (2010), a collaboration between the National Portuguese Reading Plan and the School Libraries Network Programme plays an important role in the promotion of reading literacy as a baseline to develop all kinds of other literacy abilities and empower the role of school libraries and the collaborative work between the school community and the school library. The program main goal is to install and develop libraries in state schools at every level, supplying its users with the necessary resources to read, access, use and produce information, regardless of the format. The organization and operation of the school libraries are guided by principles, namely its development within a school community perspective, calling for articulation and networking principles such as the collection that should be updated and adjusted to the students' and teachers' needs. This includes curricula supporting documents, literature collections, children and young readers and the practice of library interloan.

The School Libraries Supporting Service that is created to give continuity to the collaborative work extends its service beyond the technical work to include activities of reading promotion. In this project, to accomplish its mains goals, School Libraries Network Programme tried to respond to training needs of the teacher-librarian and of the team, either by the continuous teacher training or by higher education institutions. The teachers are also in charge of encouraging municipal working groups, in collaboration with the public library, in order to develop structured projects in the promotion of reading and literacy. This creates an awareness of the need to adopt resources sharing policies and joint organization of activities to stimulate the creation of network information management systems.

Additionally, a report on the Activities and Recommendations Made under Planning Grant for Model Saturated School Library by Marjorie Waters indicates that the services to teachers would consist of the acquaint teachers with library services and resources and newer trends in education. Librarian through relationship with teacher effectively "gets across" the idea that the library is a source of ideas as well as materials.

\subsection{The Library as Incubator Project}

The Library as Incubator Project was created by Erinn Batykefer, Laura DamonMoore, and Christina Jones, and was inspired by a discussion about creative advocacy for libraries in one of their courses at the UW-Madison School of Library and Information Studies. The mission of the Library as Incubator Project is to promote and facilitate creative 
collaboration between libraries and artists of all types, and to advocate for libraries as incubators of the arts.

Through founding and maintaining the project, they began to see that not all knowledge worth collecting for a library was written down - much of the creative skills and expertise of artists and makers in the community was only accessible by talking and learning from them. The best way to collect this information is through partnerships and programming - "programming as collection development." This new concept of collecting information and the evolution of library maker spaces has ushered in more and more opportunities to partner with local artists and makers. Most importantly, every library must look to its own community to build an individual collection of local skills and knowledge.

Annamalai, in the studies conducted in 2013 briefed that positive reading attitudes inspire positive reading experiences and encouraged higher academic achievement. In our case, PHS tried to encouraged the society located near USM to be aware of what available in the library or resource center. This will help them to transform the environment to be more warm and friendly to their audience, which is targeted to the youngsters.

\subsection{The Library as Exhibitions Space}

Exhibitions are a great way to impart information, gather feedback, and generate new ideas through discussions. Usually, an exhibition is the best place to launch or revive a product or service and get feedback on the activity from the key stakeholders and it give the opportunity to learn more about products and services they may want to buy immediately or in the near future and also gives user the opportunity to socialize and build connections. In fact, research shows that $54 \%$ of visitors to exhibitions specifically come to see new products and services; $48 \%$ come for information; $40 \%$ to keep up to date with technology; and $15 \%$ to make business contacts (Re-branding academic libraries in tough times: Attracting students through marketing, 2010).

Nowadays, exhibitions not focused on museums only but have been created by libraries, archives, and historical societies, as well as to museum online exhibitions with a significant focus on library and archival materials. Exhibition is an event organized to bring together buyers and sellers at a single venue (Exhibition, 2007). In scope of library, exhibition is also a part of marketing in promoting their services and activities.

In universities, they have long been accused of complicity in which they fail to successfully connect with everyday society or they called as with the "ivory tower 
syndrome". "Knowledge transfer" (or knowledge exchange) is increasingly seen as critical to the strategic future especially in academic institutions.

The University of Hong Kong Libraries has long recognized the significance of its position in Hong Kong Society. As the oldest and leading University in Hong Kong, and one of Asia's finest, it has a rich collection of resources that are great interest to communities beyond its immediate family, including both local and global communities. The University's new strategic direction of "knowledge exchange" has given the Library added motivation to excel in engaging the community, beyond the University as it is one of only three strategic themes.

Libraries have been hosting a series of exhibitions in the main library as well as the branch libraries of being aware that exhibitions could engage wide public participation. The exhibition themes range from library services to anything that can capture the community interests such as posters, theme books, manuscripts or bibliographies containing a list of readings on the theme recommended by the librarians, media playing, paintings, photos and other objects. This will help the users to get the knowledge about a theme via multiple sources. Some exhibitions are accompanied with talks and functions as well. Since 2005, around 42 exhibitions have been held in the main library which was contributed by the Libraries, University Faculties and Departments, individual members or organizations of the local communities (Sidorko \& Yang, 2011).

Kronin and O'Brien (2009) said that not only outline different strategies for generating cash and relevance for academic libraries, but also propose a new philosophy for libraries centered on marketing. Exhibitions also is one of the rebranding the library. Consequently, libraries need to attract and retain patrons, and re-establishing themselves as the primary information providers on campus to finding better ways in promoting the library. This can be done through marketing, which, as the authors suggest, is a philosophy traditionally at odds with that of academia. (Re-branding academic libraries in tough times: Attracting students through marketing, 2010).

\section{Benefits of Exhibitions}

In general, users can get the benefits from the following:

Product Launch: An exhibition or a trade show is the perfect platform to launch a new product or service as all parties - members of the industry, interested buyers and media are in 
attendance. This enables user to attract the attention of multiple audiences towards their product or service easily.

Buyer Database: An exhibition or a trade show is a great way to meet thousands of new buyers in a short period of time. It also enables user to collect data of said buyers in order to develop a quality database.

Build Relationships: Exhibitions or trade shows are excellent places to network with potential buyers and client, thus, giving user the opportunity not only to develop connections but also personal relationship with said buyers and clients.

Inform \& Educate: Exhibitions and trade shows are an opportunity to inform and educate all attendees from industry buyers to general public about the benefits of their products and services. Moreover, user can conduct demonstrations or let buyers try the product or service to gain appreciate of the product or service and negate any objections.

Ready Feedback: Once a buyer or client has tried and tested a product or service, user can get request for immediate feedback. This will serve two purposes - the first, user can gauge how well the product or service is received and two, gain inputs about what other features or products the prospective buyer or client is interested in.

Instant Sales: Exhibitions and trade shows enable one-on-one interactions with their target market. This interaction can help user overcome buyer doubts, thus, enabling them to accelerate the decision making process (buying process). User can also kick start their revenue by selling their products and services at their stall at the exhibition or trade show.

\subsection{RE-IMAGINING LIBRARY AS A LEARNING CENTRE - FOR CREATIVITY, INNOVATION AND PLAY}

PHS Reading Community initiative in nurturing reading habits shared almost the same objectives with the project that were called "Inspiring Readers" in the articles written by Peoples and Ward (2007) that lined up the reason of their project such as to:

i. engage target groups, principally children, young people and emergent readers, in reading activities; 


\begin{abstract}
ii. develop and provide training for library staff in both authorities; and
iii. Roll out good practice.
\end{abstract}

In the articles, they share how to encourage readers' development as well as to strengthening the work force and responsibility of the library and librarians. In realization of the roles we played, it is crucial to continue our journey in making the reading awareness felt by all people not only by people who practicing their academic roles but also to the peoples near us. It might as well enable them to shift the paradigm and remove the negative stigma that long stays in the society. Reading is the tools to achieving power; power in mind and power of the soul.

\title{
3.1 PHS Community Network
}

\section{a) PHS@Chemor}

PHS@ Chemor is a community service activity organized by two main committees at PHS; namely Reading Campaign Committee and Customer Day Committee in partnership with Darul Ridzuan Advanced Student Teaching Club (KUSISDARI), USM students' club who have been actively involved in community networking program especially in Perak.

This program was held on $14^{\text {th }}$ and $15^{\text {th }}$ May 2010 at the Syed Idrus Primary School, Perak involving 200 selected students from year 1 to year 6 . This school which located in a rural area was selected because it has big potential to develop as one of an excellent rural school with the little support and assistance from the community.

The committee has organized various activities to inspire students about the importance of reading from an early stage. The activities that been held are reading skills workshop, information literacy training and motivational talks. Collection development projects have been carried out to increase the amount of material available in the resource center which has been the centre for dissemination of information in the school.

The program has been successfully implemented and hopefully this initiative will further motivate the school community in becoming a high-performing school in the future. PHS@Chemor has become a flagship community project at PHS. Hopefully this project will be benchmarked by other libraries in carrying out community service projects in the future as it has highlighted the role of the library in supporting "the bottom billion" to acquire knowledge and information. Furthermore, the project is parallel with the mission of USM in strengthening and empowering talent as well as to enhance socio-economic of community by reaching to the bottom billion. 


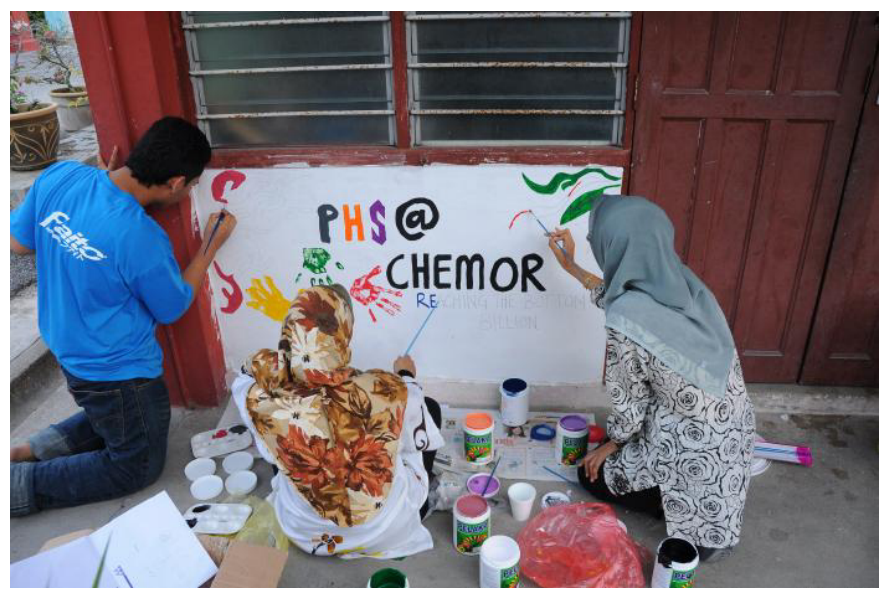

Figure 1: Mural painting by the committee members

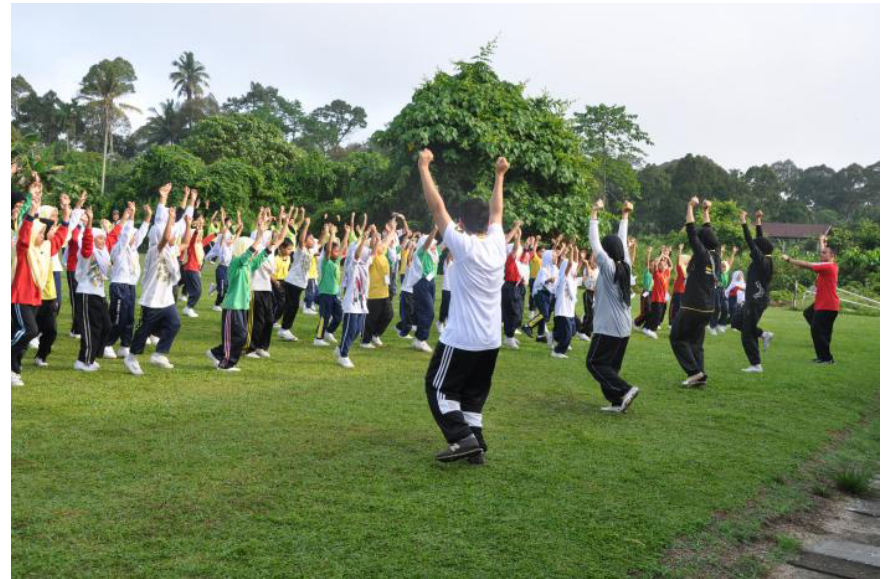

Figure 2: Facilitating exercise with the participants

\section{b) PHS@Koperasi Tadika Minden}

USM is a pioneer university that strives to empower and enable future talent to create generations of knowledge to transform their welfare. Thus, Reading Campaign Committee in collaboration with students from the School of Education and Koperasi Tadika Minden, USM held a community programs on $14^{\text {th }}-15^{\text {th }}$ May and 20th June 2012 took place at Koperasi Tadika Minden located inside USM campus.

Koperasi Tadika Minden, USM was selected as the location of the program considering it as an educational institution in early childhood in the campus which holds the mission to cultivate love towards knowledge and reading. Therefore, PHS has taken this 
opportunity to organize a community program with a focus on giving consciousness to the school community about the importance as well as the benefit of reading from early stages.

In addition, this program is also a cornerstone where the school's library will be developed as a knowledge exchange centre among school community. The three days program focused on rebranding the interior and exterior library looks, to re-organize and reclassify library collection and establishment of computerized library system. Koperasi Tadika Minden Open Day was held in conjunction with the kindergarten's Reading Month Campaign. Lots of activities were organized including puppet show, coloring contest, jigsaw puzzles contest, spell-it-right, and other games. An official launching ceremony of the library also was organized and attended by top management of library and school.

Implications or the output after the program are as follows:

i. The collection is classified and well-organized. Classification is done according to the format of material resources such as reference collections, series, fiction, picture and so on.

ii. A computerized library system, where borrowing and returning process is made easy through online.

iii. Collection and user data can be accessed through a computerized library system at any time in need.

iv. Reports for each transaction can be generated through the library system especially for justification to the top management.

v. All collection is accessible through the online public access catalog (OPAC).

vi. The library are decorated and painted to suit preschool children. This makes the room more attracted and students eager to visit the library more regularly.

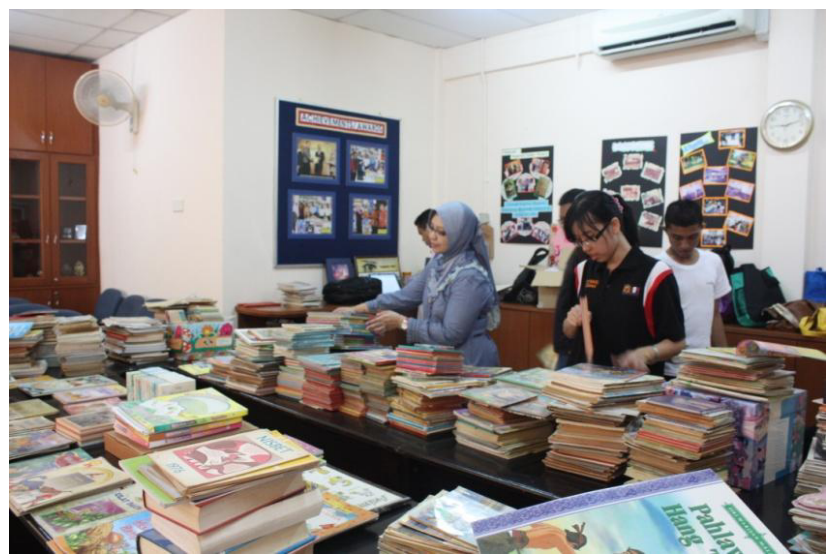

Figure 3: Sorting and classification of reading materials in progress 


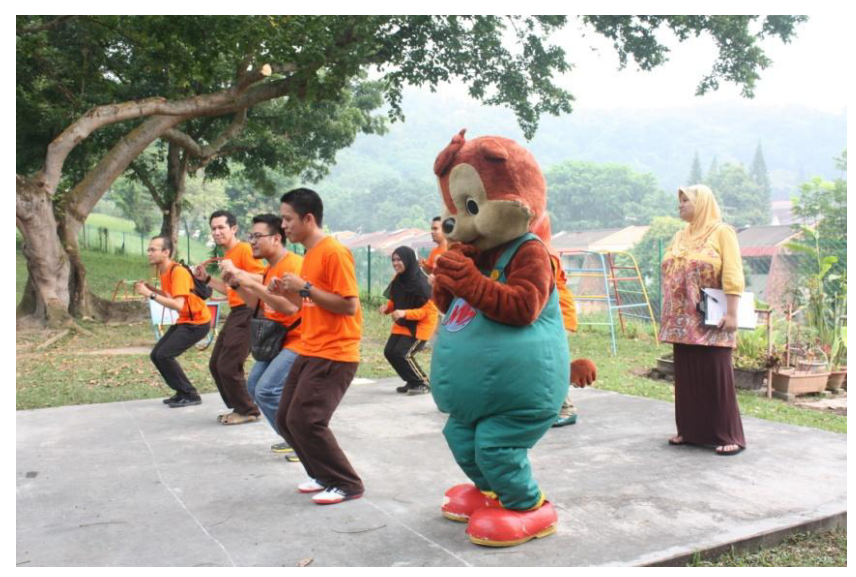

Figure 4: Having fun with students by doing chicken dance

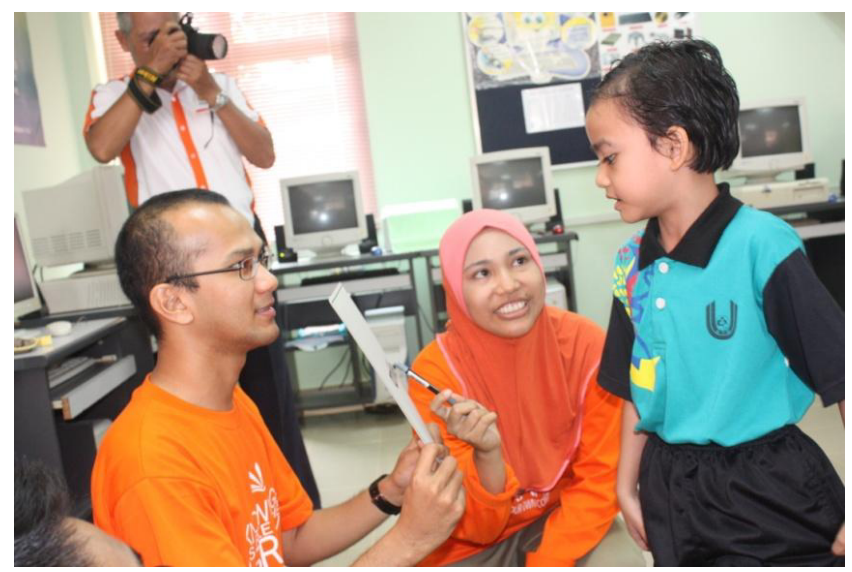

Figure 5: Simple quiz for students

\section{c) PHS@Tadika Lestari IImu}

PHS continues to organize community network program within USM campus at Tadika Lestari Ilmu, Islamic Center, USM. This time, Reading Campaign Committee has partnered with the Islamic Center together with 12 students from the Volunteer Club, USM to accomplish this two days program which held on $27^{\text {th }}$ and $28^{\text {th }}$ march 2013 . The team was divided into three groups; painting, mural and system. Painting team focuses on re-paint the library with attracted color, while mural team come out with creative mural to suit the school's need, and system team do arrange the collection according to subject and perform input of data into library computerized system.

Previously, the books in the library are not allowed to be borrowed out on various constraints. With the installation of the new systematic library system, the management of kindergarten agrees to provide opportunities for students to borrow out books to be read at 
home. In addition, this can be a milestone for students to enhance their reading habits. Via the system, all borrowing transaction can be recorded; thus can be a good justification for acquisition budgeting in the future.

After the first phase program, on $15^{\text {th }}$ May 2013 the team again organized an Open Day with the students with variety of fun activities such as ice breaking session, cheer loud, quizzes and coloring, At the end of the program, prizes were given to the winners and all guests were invited to see the improvements that have been made to the library.

Even though this kind of program requires a sacrifice of time and energy among the committee members but it gives great impact to the society.

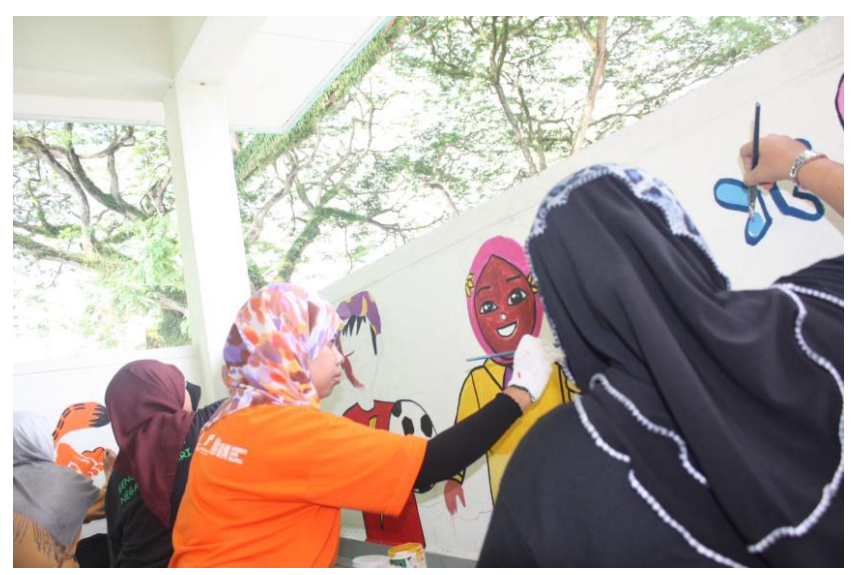

Figure 6: Mural in making

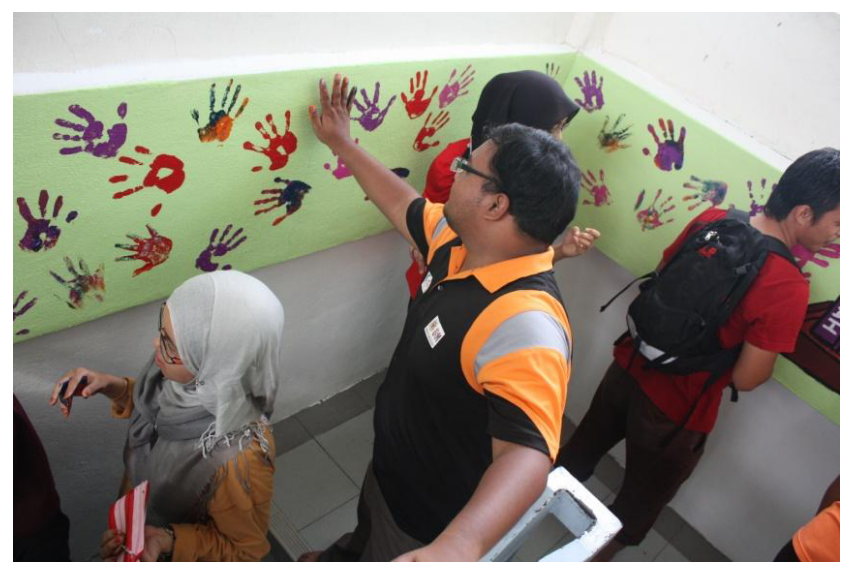

Figure 7: Leaving a legacy 


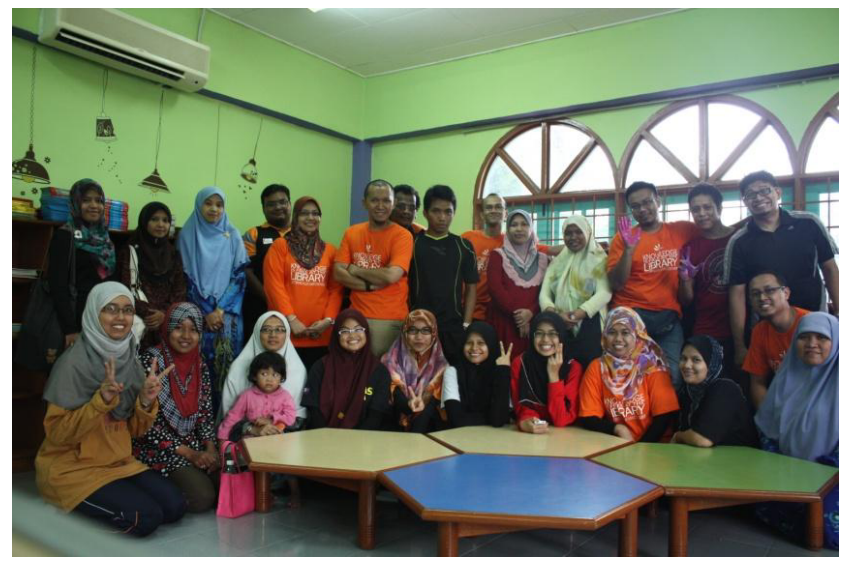

Figure 8: Happy faces after the program

\subsection{PHS EXHIBITION}

a) Reading Independence

This program was organized to support the Love Reading Campaign and simultaneously celebrate the $52^{\text {nd }}$ Malaysia Independence Day. Various activities were carried out during this period with the aim to open eyes and minds of the people to appreciate the true meaning of independence.

Among the activities include Independence Exhibition in collaboration with the National Archives and Museum \& Gallery Tuanku Fauziah USM. The exhibition was held from $12^{\text {th }}$ to $31^{\text {st }}$ August 2009 at PHS foyer. It is a multi-dimensional exhibition which exhibit paintings, photographs, prints, fossils, old manuscripts, swords, shields, cloth, digital prints and video projection.

For this program, PHS has brought a selection of films and documentaries for the Merdeka Ria Movie Show event. This special screenings took place in the PHS Leisure Area. All the films and documentaries such as Sarjan Hassan, Bukit Kepong and 1957 Hati Malaya are provided National Archive of Malaysia and PHS Media Services Division.

The whole event was inaugurated by the USM Vice-Chancellor, Professor Tan Sri Dato. Dzulkifli Abdul Razak. Boria, a local cultural form of performance and choir performances being performed by PHS staffs during this events. Feedback that we got from the visitors, they're very satisfied with the quality of exhibition and activities that have been implemented. 


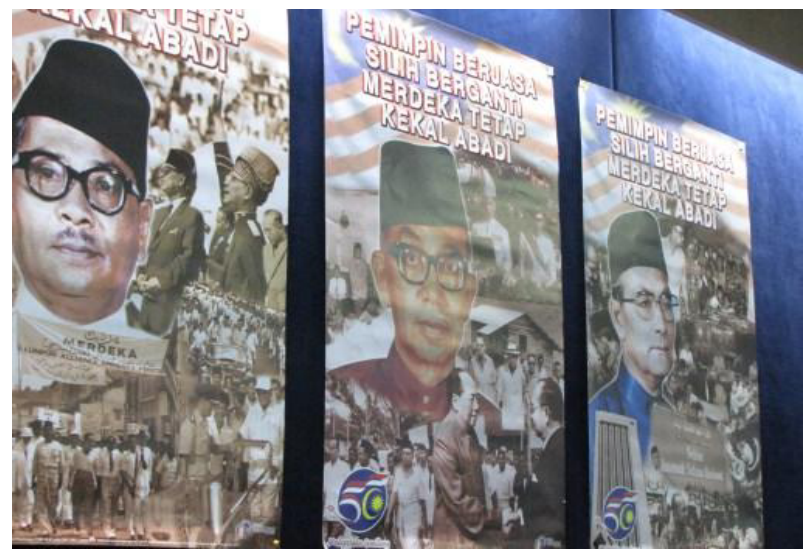

Figure 9: Posters of former Prime Ministers

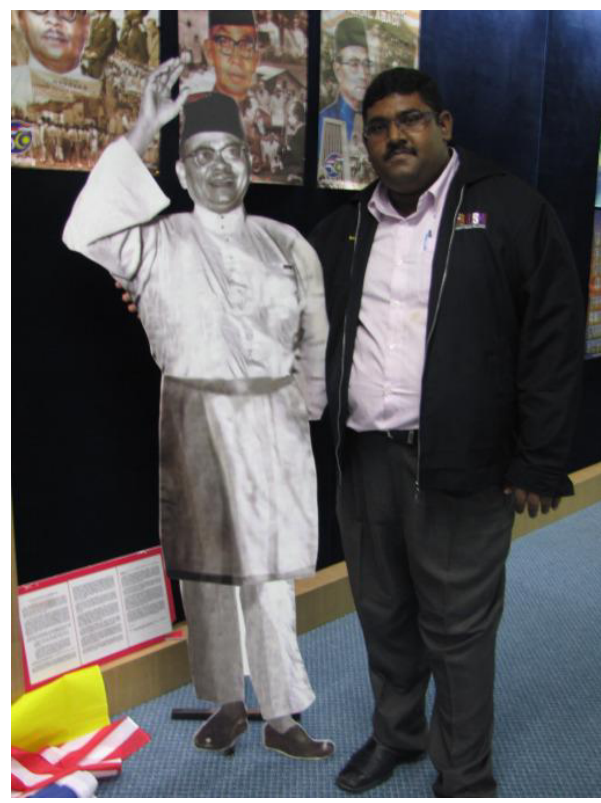

Figure 10: Committee with a model of first former Prime Minister

\section{b) Women in Poetry}

In conjunction with International Women's Day (March 8) and World Poetry Day (March 21), Library Reading Campaign Committee has organized an exhibition under the theme 'Women and Poetry' from $7^{\text {th }}$ March to $4^{\text {th }}$ April 2014. This exhibition allowed visitors to get live experience through seeing, touching, reading and watching the exhibition materials consisting of printed materials and media collection. In addition, there are also a collection of women's clothing and jewelry that is part of the collection of Museum and Gallery Tuanku Fauziah, USM. 
During this program, a nonstop movie screening also was organized for 13 days with local and international films such as Sepet, Musang Berjanggut, Puteri Gunung Ledang, Mukhsin, Maria Mariana, Baby Mama, Cinderella 2, Romeo and Juliet, Joan of Arc, The Little Mermaids, The Little Mermaids 2, Mary Poppins and The Silent Feminist.

On $4^{\text {th }}$ April 2012, Poetry Declamation Contest was held at the Library with participation from the USM students and staff who are also poetry-lovers. All participants need to compose their own poem and recite it during the day. At the same day of Poetry Declamation Contest, a closing ceremony also was held which was inaugurated by the Chief Librarian; Tuan Haji Mohd Pisol Ghadzali. During the ceremony, the top book borrowers among the students and staffs received special prizes as appreciation for their support towards library. This program has received good responses from the customers which are to create awareness of the sacrifices of women around the world especially the sacrifices of mothers.

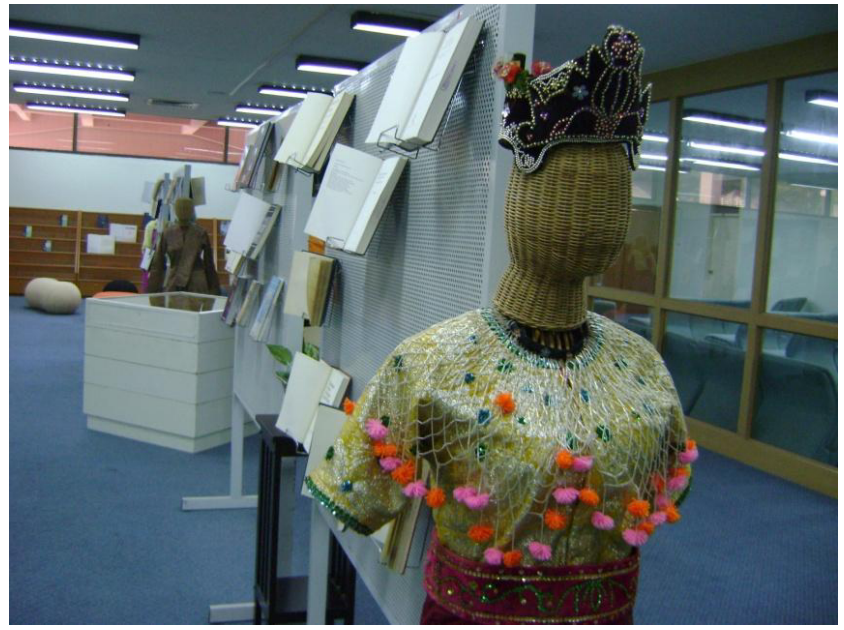

Figure 11: Traditional women cloth and books about women

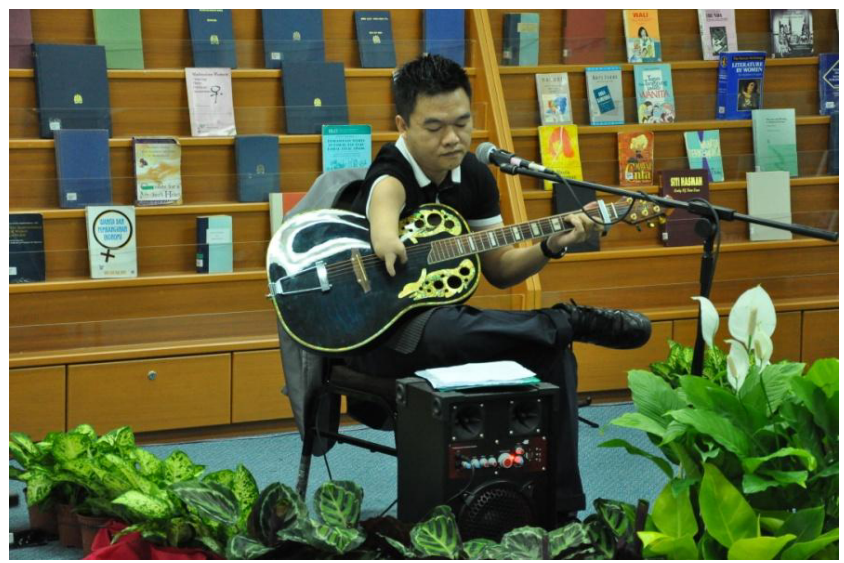

Figure 12 One of participant declamate a poem 


\section{c) Muhammad Haji Salleh: Knowledge and Literature Traveller}

Hamzah Sendut Library, in collaboration with Centre for Policy Research and International Studies (Cenpris) and Dewan Bahasa dan Pustaka hold an exhibition entitled Muhammad Haji Salleh: Knowledge and Literature Traveller from $18^{\text {th }}$ April $2012-31^{\text {st }}$ May 2012, at PHS. This exhibition was originally expected to last for two weeks, but due to overwhelming response from visitors and to provide greater opportunities to all to appreciate the the life of a writer, then it is extended to the end of May 2012.

Muhammad Haji Salleh became publicly known in Malaysia as a writer during late 1960s however he actually had written earlier. He spends his life abroad, and began writing poetry, mostly in English. When he returns to the homeland, his poems start to get attention and critics. He began writing since at the Malayan Teachers' Training College in Brinsford Lodge, England, in 1963. Because of his educational background in both Malay and English, he wrote in both languages. The poems in English language are heavily influenced by TS Eliot and W.H. Auden that he is admiring at that time.

On $23^{\text {rd }}$ April 2012, Exhibition Opening Ceremony was held at the Hamzah Sendut Library 1 and officiated by Deputy Vice-Chancellor for Research \& Innovation, Professor Asma Ismail. This ceremony was accompanied by poetry recital performances presented in various languages by lecturers and students of the School of Languages, Literacies and Translation in Mandarin, Spanish, Thai and Japanese, and ends with a recitation by Muhammad Haji Salleh in Malay language. Moreover, Professor Asma Ismail not only officiated the event, but also recited a poem in Spanish.

Books by Muhammad Haji Salleh, his handwriting paper, personal items, personal anecdote, travel maps and other literatures were presented in the exhibition. This program aimed to provide deeper insights about literary life of a national laureate as well as foster a love of literature that has always been close to our heart. In conjunction with this program, Muhammad Haji Salleh has composed a poem entitled 'Perpustakaan' especially for Hamzah Sendut Library. A special blog (http://pameranmhs.wordpress.com/) been created for people to know more about Muhammad Haji Salleh. 


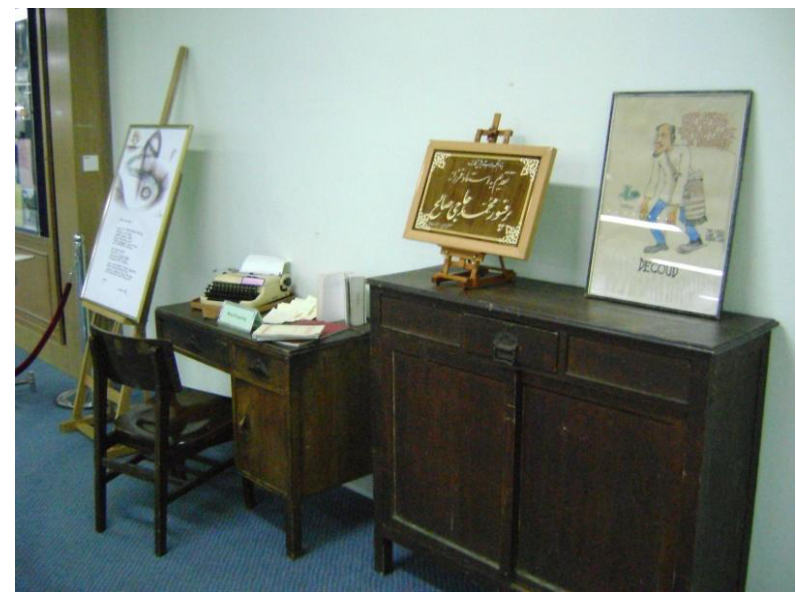

Figure 13: Part of Muhammad Haji Salleh personal collections

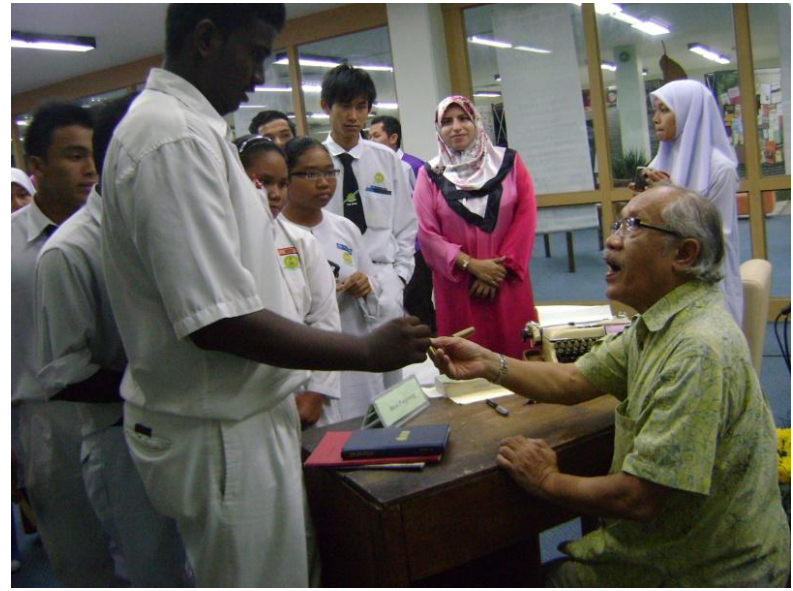

Figure 14: Muhammad Haji Salleh is signing autograph for the audiences

\subsection{PHS Sharing Is Caring Program}

\section{a) Booklovers Corner and Book Donation Box}

Book Lover's Corner is an initiative of PHS Reading Campaign Committee aims to develop reading culture among the community of USM. The theme "sharing is caring" is a key pillar of this activity. Realizing that everyone has old books to be donated, this corner main objective is to provide platform for USM community to share reading material for mutual benefit. Through this Corner, customers are free to donate, read and even take home reading materials available here. Indirectly, this corner is expanding by its own with a minimum commitment of the committee.

Following a series of discussions by Reading Campaign Committee, Book Lover's Corner was finally launched on $17^{\text {th }}$ January, 2012 in front of PHS 1. A total of 30 books 
have been placed on the first day of its establishment. At the beginning, very few numbers of books are donated but over the time, the number of books donated has been increase and some USM members are regular depositors for this Corner.

In the first year, a total of about 500 books and magazines have been donated to this corner, whereas from January to May 2013, PHS has received donation of 442 reading materials. Looking at the overwhelming and positive response for this Corner, a decision was taken to establish a second Book Lover's Corner nearby PHS 24-hour reading area. This new Corner starts to operate on $1^{\text {st }}$ April 2013 and to date PHS has received 245 pieces of reading material that can be utilized by all walks of life.

The idea of sustainable sharing is expanded with the creation of the Book Donation Box which commenced operations on $4^{\text {th }}$ February 2013. Throughout the year, this box has received a total of 1328 copies of reading materials. The books from the Donation Box are donated to various resource centers or libraries in needs through PHS community outreach activities, and some are place at Book Lover's Corner. This initiative only incurs a minimal cost because it was made by reusing existing materials and with the help of creative people among the committees. Hopefully, this small effort can brings lasting impact in promoting sustainable sharing as well as to enhance reading culture in the campus.

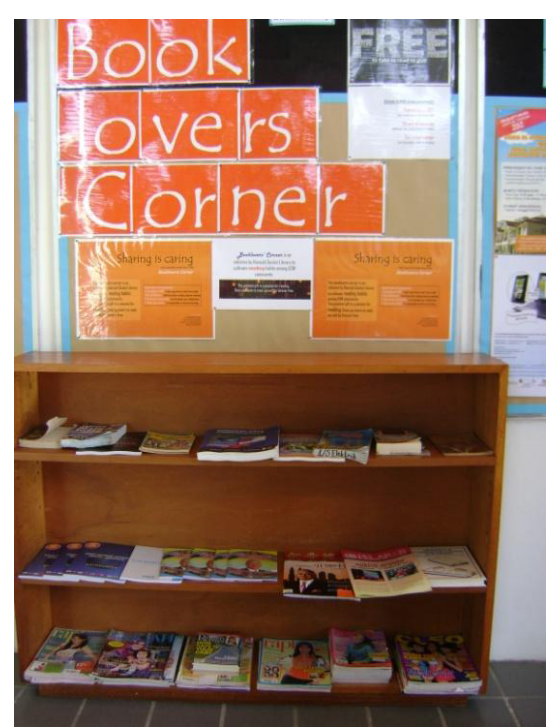

Figure 15: Booklover's Corner

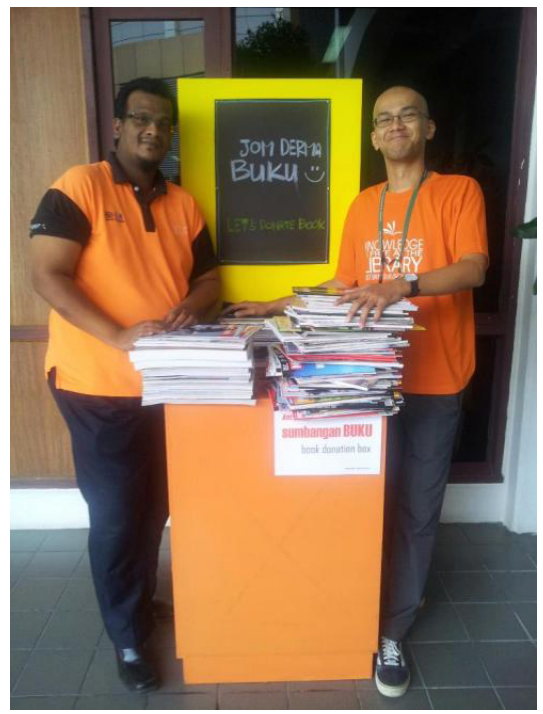

Figure 16: Collecting books from donation box 


\subsection{CONCLUSION}

Library is synonymous with reading. With more than a million copies in its collection, it is library's obligation to attract customers to take advantage of those reading materials. Moreover, PHS should play a vital role to enhance the reading culture not only to the USM community, but also to the general public out there.

PHS realizes that the expertise to manage reading materials should not be keep by its own, but rather to be shared to others in need through community programs. Besides that, the efforts to promote reading in the library on selected topics is realized through exhibitions, while sharing is caring initiatives is carried out through book lovers corner and books donation box.

Although these programs are run in small-scale, it brings a lasting impact and benefit to all. PHS programs certainly will not stop here; rather it will be the milestone for other projects with higher impact to all.

\section{REFERENCES}

Annamalai, S., \& Muniandy, B. (2013). Reading habit and attitude among malaysian polytechnic students. International Online Journal of Educational Sciences, 5(1), 3241.

Buzan, T. (2006). Buzan bites :Speed reading.

Clay, M. M. (1991). Becoming literate: the construction of inner control: Heinemann.

Exhibition. (2007). Bloomsbury Business Library - Business \& Management Dictionary.2937.

Gaarder, J. (2002). Books for a world without readers. Basil: 28th Conference of the IBBY.

Ghoting, Saroj Nadkarni and Martin- _ Pamela. (2005). “Early literacy storytimes@your library ${ }^{\circledR}$ : Partnering with caregivers for success." American Library Association, 4570.

In the Library with the Lead Pipe. Retrieved from http://inthelibrarywiththeleadpipe.org

James Murdock. 2011 Beauty and the book: Libraries in the digital age raise questions about the place of books. Architectural Record, pp. 56.

Kronin, K., \& O’Brien, T. (2009). Practical low-cost marketing measures: The experience of Waterford Institute of Technology Libraries. New Library World, 110(11/12), 550560. 
Martins, Ana Bela \& Marques, Alexandra. (2010). "Promoting a reading culture in school community: how to engage reading activities cross curricula, directors, teachers, students, parents, administrative services, local authorities, public libraries and other partnersRelating a project." IASL, SLAQ, 1-5.

Mason, J. M. (1977). Reading readiness: a definition and skills hierarchy from prescholers' developing conceptions of print. University of Illinois Center for the Study of Reading, University of Illinois at Urbana-Champaign.

Peoples, A., \& Ward, T. (2007). "Inspiring readers": a cross border reader development project. New Library World, 108(5/6), 218-228.

Poulter, A. (2007). On reading "the librarian and the art of reading". Library review, 56(2), 113-116.

Prendergast, Tess. (2011). "Beyond storytime children's librarians collaborating in communities" Children and Libraries, Spring, 20-40.

Public Library Use: ALA Library Fact Sheet 6. Retrieved from www.ala.org/ala/professionalresources/libfactsheets/alalibraryfactsheet0.cfm

The Library as Incubator Project. Retrieved from http://www.libraryasincubatorproject.org

Re-branding academic libraries in tough times: Attracting students through marketing. (2010). Strategic Direction, 26(5), 23-25.

Sidorko, P. E., \& Yang, T. T. (2011). Knowledge exchange and community engagement: an academic library perspective. Library Management, 32(6/7), 385-397. 